\title{
CIÊNCIA E FÉ NA ALTA ESCOLÁSTICA: MEDIAÇÃo OU CONTRADIÇÃO?
}

Science and faith in high scholasticism: mediation or contradiction?

Rogério Miranda de Almeida

Irineu Letenski *

Resumo: O objetivo principal destas reflexões é o de se perguntar não somente pelo estatuto científico da teologia nos séculos XII e XIII, mas também pela possibilidade mesma de uma intelecção dos dados da fé, ou da revelação. Se, com Pedro Abelardo, a teologia adquire no século XII o status de ciência e, enquanto ciência, ela se consolidará no século XIII com a fundação das universidades e a entrada completa de Aristóteles no Ocidente latino, a relação fé e ciência não se desenrolará de maneira tão harmoniosa como se poderia imaginar. Pelo contrário, ela se intensificará e se tornará ainda mais aguda à medida que se aprofundará e se explicitará, no século XIV, o abismo que separa estes dois domínios do saber. Com efeito, esta problemática, que remonta aos primeiros séculos da era cristã, se coloca agora sobre um novo nível epistêmico mais urgente e mais desafiador ainda: como falar racionalmente, ou cientificamente, de Deus?

Palavras-chave: Ciência. Fé. Razão. Revelação. Abelardo. Tomás de Aquino.

Abstract: These reflections aim not only at investigating the scientific statute of theology in the 12th and 13th centuries, but also the very possibility of the intellection of faith, or revelation. If, with Peter Abelard in the 12th century,

\footnotetext{
* Rogério Miranda de Almeida é doutor em filosofia pela Universidade de Metz (França) e em teologia pela Universidade de Estrasburgo (França); leciona filosofia no programa de pós-graduação da PUCPR, filosofia na FASBAM e teologia sistemática no Studium Theologicum (Curitiba). Irineu Letenski é doutor em filosofia pela PUCPR; é diretor e professor de filosofia da FASBAM. Artigo enviado em 31/03/2016 e aprovado para publicação em 17/10/2017.
} 
theology receives the status of science and, as a science, consolidates itself throughout the 13th century with the creation of universities and the complete reception of Aristotle in the Latin world, the relation between faith and science will not develop in a so harmonious way as one can imagine. On the contrary, it will intensify and become even more acute as, in the 13th century, the abyss separating these two domains of knowledge will become deeper and more explicit. In fact, this issue, which goes as far back as the first centuries of the Christian era, now appears in a more urgent and challenging epistemological way: how can one speak rationally, or scientifically, about God?

Key-words: Science. Faith. Reason. Revelation. Abelard. Thomas Aquinas.

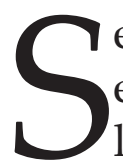
e, durante a Idade Média em geral, não havia praticamente fronteira entre a filosofia e a teologia, nos séculos XII e XIII - quando a Escolástica atingirá o seu apogeu - um novo fator virá mudar e, de certa maneira, complicar esta relação. É quando à teologia, que até então era denominada pelas expressões: sacra doctrina, sacra pagina, doctrina christiana, será assinalado o papel de "ciência". Foi, efetivamente, com Pedro Abelardo (1079-1142) que a doutrina cristã passou a ser considerada e estudada como um conjunto sistemático das doutrinas da fé cristã, adquirindo, portanto, o estatuto de ciência. Mas o que se entende por "ciência" nos séculos XII e XIII?

De fato, o conceito de ciência é hoje tanto mais difícil de se delimitar quanto mais se devem levar em conta, além de sua carga semântica, as diferentes perspectivas que marcaram as vicissitudes do saber a partir da antiguidade clássica grega. De resto, quando atualmente falamos de "ciência" empregamos habitualmente este termo no plural, porquanto foi a partir de Immanuel Kant - na sua obra intitulada: Princípios metafísicos da ciência da natureza - que se operou a distinção entre, de um lado, a ciência propriamente dita, cujo objeto se dá a partir de uma certeza apodítica, necessária, a priori, e, de outro, a ciência em geral, que é baseada num conjunto de conhecimentos ordenado em conformidade com princípios e resultando em um ou em vários sistemas. ${ }^{1}$ A esta distinção viria ajuntar-se aquela outra de Wilhelm Dilthey - no estudo intitulado Introdução às ciências do espírito (1883) - cujo ponto de partida remonta a Hegel. Segundo Dilthey, existem as "ciências do espírito" (Geisteswissenschaften) e, em contraste com estas, as ciências da natureza. As primeiras designam o âmbito das disciplinas que têm por objeto o mundo histórico-social, no qual se exprimem e se materializam as produções culturais do homem.

${ }^{1}$ Cf. KANT, I. Schriften zur Naturphilosophie, 2003, Vorrede, pp. 11-12. 
Já as ciências da natureza se voltam para o mundo objetivo do homem ou, mais exatamente, para os fenômenos, os dados e, enfim, para aquelas realidades positivas, subsistentes, que se encontram fora do homem. ${ }^{2}$

Se agora retornarmos à concepção clássica da "ciência", constataremos que ela se encontra pela primeira vez em Platão e, mais exatamente, no Livro VII da República, onde o filósofo designa pelo termo de "episteme" o ápice ou a acuidade máxima pela qual o sujeito atinge o objeto de sua investigação. Mas este mesmo saber, ou esta mesma busca, se manifesta sob uma dupla modalidade: há, de um lado, a diánoia, que se desdobra sob a forma de um pensamento discursivo, e, de outro, a episteme propriamente dita, que é o conhecimento perfeito, ou relativamente perfeito, porquanto o sujeito se move - e não pode mover-se senão - no reino da linguagem, da significação ou, parafraseando Lacan, da incompletude do simbólico do real. Ajunte-se que estes dois movimentos - a diánoia e a episteme - constituem aquilo que Platão denomina nóesis, que é o conhecimento voltado para o ser, ou para a ousía, enquanto que a opinião, isto é, a doxa, pertence à esfera do vir-a-ser, ou da génesis. ${ }^{3}$

Quanto a Aristóteles, ele irá igualmente diferenciar os vários graus epistêmicos da hierarquização do saber, na medida em que existem diversas artes (téchnai) e diversas disciplinas, ou ciências, que culminam na sabedoria (sophia) propriamente dita, que é a investigação das primeiras causas e dos princípios. Saliente-se, contudo, que é através de uma frase ambígua e controversa que o Estagirita conclui a primeira seção do Livro A da Metafísica: "É, pois, evidente que a sabedoria (sophia) é uma ciência (episteme) que diz respeito a certos princípios e a certas causas". ${ }^{4}$

É, portanto, a partir e através da tradição platônico-aristotélica do conceito de ciência, isto é, a ciência entendida como uma busca racional daquilo que é necessário, eterno, imutável, autossuficiente e subsistente, que a Escolástica, a partir do século XII, irá tentar compreender e, mais do que compreender, explicar racionalmente os dados da revelação, ou da fé. Não se pode, porém, elidir esta questão: pode a teologia ser considerada uma "ciência", isto é, um conjunto racional e sistemático da doutrina cristã se ela tem como base e referência principal as Escrituras e, portanto, uma sabedoria focada na inspiração e na revelação? Em outros termos, fé e razão - para nos servirmos deste binômio que pontilhou e marcou todo o desenvolvimento do pensamento cristão - são conciliáveis uma com a outra? E se pensarmos, no apogeu da Escolástica, quando a problemática

${ }^{2}$ Cf. DILTHEY. W. Einleitung in die Geisteswissenschaften., 1990. Veja em particular: Erstes Einleitendes Buch, II, pp. 4-14.

${ }^{3}$ Cf. PLATÃO. La République, 2004, VII, 533d-534a.

${ }^{4}$ ARISTÓTELES. Metafisica, 2000, A, 1, 982a. 
se desloca mais propriamente para o binômio fé e ciência, a questão que não se pode de forma alguma elidir é a de saber se se pode com toda propriedade falar de uma ciência da fé, ou da revelação. São estas duas esferas mutuamente opostas, antitéticas, ou complementares entre si? Em outros termos, admitem elas uma mediação ou se apresentam irremediavelmente separadas e irreconciliáveis uma com a outra? Esta é a razão pela qual achamos por bem lançar primeiramente uma visão panorâmica sobre o século XII para, assim, melhor vislumbrarmos os desdobramentos e a diversificação do conhecimento a que se chegou no período da Alta Escolástica.

\section{O século XII: uma panorâmica da filosofia e da teologia}

O saber filosófico-teológico que predominou ao longo da Idade Média, e notadamente aquele que vincou de maneira essencial a Escolástica latina, teve como origem e pano de fundo o pensamento de Platão e, mais exatamente, a sua reinterpretação efetuada pelo neoplatonismo. Note-se, contudo, que este neoplatonismo - expresso nas filosofias de Plotino, Porfírio, Proclo, Dionísio Areopagita e outros - tornou-se conhecido e difundido graças às traduções latinas realizadas, por exemplo, por Mário Vitorino e Escoto Erígena. Agostinho aparece como o principal veículo da inspiração e da influência neoplatônicas que iriam marcar as principais correntes do pensamento medieval até a entrada de Aristóteles no mundo latino no final do século XII e inícios do século XIII. Note-se, contudo, que a entrada de Aristóteles no cenário latino não veio de modo algum eclipsar a presença e a influência do neoplatonismo no seio daquelas correntes em que ele se desenvolvera. De resto, na grande condenação de 1277 pelo arcebispo de Paris, Étienne Tempier, seria o neo-agostinismo, e não o aristotelismo que iria triunfar. A propósito do platonismo, ou dos platonismos que vigoraram ao longo da Idade Média, deve-se destacar a releitura que se efetuou de Platão a partir da Escola de Chartres, cujo primeiro fulgor intelectual remonta à última década do século $X$, com Fulberto, e cujo brilho máximo foi alcançado no século XII com Bernardo de Chartres. Além de Bernardo de Chartres, foi também responsável pelo florescimento chartreano o seu discípulo, Guilherme de Conches. Não menos importante neste século XII foi a Escola de São Victor, situada em Paris, na margem esquerda do rio Sena, extremidade sudeste do Quartier Latin.

No Ocidente latino, eram escassas as traduções que se possuíam de Platão e de Aristóteles diretamente do original grego. Do primeiro, dispunha-se de uma versão fragmentária que Cicero havia operado sobre o Timeu e de outra tradução, mais completa, realizada por Calcídio, que a enrique- 
cera com um comentário inspirado noutro comentário desenvolvido por Posidônio. Existiam também outras versões de extratos de diálogos, tais como o Mênon, o Fédon e, mais escassamente ainda, a República. Todavia, em meados do século XII, Henrique Aristipo traduziria o Mênon e o Fédon integralmente. Quanto a Aristóteles, a leitura que dele se fazia até o final do século XII era, na sua maioria, oriunda das versões e dos comentários que tecera Boécio a partir das obras lógicas. No que diz respeito aos outros escritos do Estagirita, a interpretação que predominava era aquela derivada das traduções árabes e siríacas, bem como dos comentários desenvolvidos pelos mestres Avicena (980-1037) e Averróis (1126-1198). Domingos Gundisalvo (c. 1115-c 1190), arquidiácono de Segóvia, juntamente com o seu colaborador, João Hispano, traduziu do árabe para o latim uma parte considerável das obras de Aristóteles. Nos seus tratados, porém, nota-se uma evidente influência do chamado "emanatismo" neoplatônico proveniente das interpretações de Avicena e de Avicebron (c. 1020 - c. 1058). Foi, com efeito, através da Espanha, da Sicília e de Nápoles que a filosofia oriental adentrou o mundo ocidental. Na Espanha, por exemplo, e mais especificamente, em Toledo, desenvolveu-se um círculo de tradutores que verteram para o latim um grande número de obras filosóficas e científicas de pensadores como Alfarabi (c.870-c.950), Algazel (1058-1111), Avicena e, notadamente, Aristóteles. Dentre estes tradutores se destacam, além de Domingos Gundisalvo e João Hispano, Gerardo de Cremona e Miguel Escoto, que permaneceu em Toledo até 1220. É provável que por volta de 1230, na corte de Frederico II, em Nápoles, Miguel Escoto tinha também empreendido uma tradução de Averróis. De resto, ao findar-se a primeira metade do século XIII, por volta de 1243, quase todos os escritos de Averróis já se encontravam vertidos para o latim. Convém, no entanto, notar que, já na primeira metade do século XII, começavam a circular - embora de maneira prudente e discreta - as primeiras traduções da filosofia natural e da metafísica aristotélicas feitas diretamente do grego pelo canonista Tiago de Veneza. Era, no entanto, necessário esperar até a segunda metade do século XII e, principalmente, até a primeira metade do século XIII, para que o pensamento do Estagirita se tornasse plenamente conhecido no mundo latino. Tudo isso aconteceu, conforme avançamos mais acima, de maneira gradual: primeiramente, no século XII, através das traduções feitas a partir do siríaco e do árabe na Sicília e em Nápoles. $\mathrm{Na}$ Inglaterra, o primeiro chanceler da Universidade de Oxford, Roberto Grosseteste (1170-1253), verteu para o latim a Ética a Nicômaco. Contudo, a tradução de grande envergadura do corpus aristotélico - feita diretamente do grego - só seria realizada na primeira metade do século XIII, por Guilherme de Moerbeke (1215-1286), dominicano de origem flamenga e amigo do também dominicano Tomás de Aquino, que lhe sugeriu a realização deste ingente empreendimento. Note-se, contudo, que todas essas traduções traziam mais ou menos a marca de uma interpretação neoplatônica identificável no pensamento e nos comentários realizados por Avicena, 
Avicebron e Averróis. De resto, elas exercerão um papel fundamental no desenvolvimento do discurso teológico, porquanto a teologia, até então reduzida a comentar as Escrituras e os Padres da Igreja, contava quase exclusivamente com as artes liberais e, notadamente, com aquelas que formavam o trivium: a retórica, posta em relevo pela tradição agostiniana, a gramática, tal como era praticada pela Escola de Auxerre, e a dialética, também de derivação estoica, mas transformada na arte da disputação, das divisões, das cavilações e ilações que se multiplicavam ad infinitum.

Dentre os pensadores da Escolástica latina, se destaca a figura de Anselmo de Aosta (1033-1109), arcebispo de Cantuária, que propôs um ideal teológico de inspiração agostiniana apto a integrar a dialética à teologia e, consequentemente, a oferecer um exemplo de meditação sobre a racionalidade da fé. Ademais, o renascimento filosófico-teológico que se enceta no início do século XII se expandirá pelas décadas seguintes e propiciará, no final do século, o surgimento de uma nova lógica que constitui a segunda parte do Organon: os Analíticos, os Tópicos e os Elencos. Disto resultará a introdução, senão de uma nova teoria da ciência, pelo menos de uma nova técnica da probabilidade. Segundo M.-D. Chenu, trata-se de algo diferente de uma simples tábua de predicamentos, porquanto a própria dialética passa do regime das sete artes liberais - cujo modelo remonta a Marco Terêncio Varrão - para a qualificação de um método tendente cada vez mais à reflexão e à investigação. Ainda segundo Chenu, o principal paladino desta nova lógica foi João de Salisbury. Entrementes, Toledo se impunha - conforme fizemos mais acima ressaltar - como o centro onde se traduziam os escritos de Aristóteles e de seus comentadores árabes. Foi também em Toledo que surgiram naturalistas e médicos filósofos que inauguraram uma nova era e que, por isto mesmo, manifestavam um certo desdém com relação aos dialetas de Paris. ${ }^{5}$

Na primeira metade do século XII, duas disciplinas principais constituíam o ensino da doutrina cristã: a Sacra Pagina (Sagrada Escritura) e o Direito Canônico, que era a sistematização do material normativo que havia regido a vida jurídica da Igreja. As leis que formavam o Direito Canônico foram reunidas no famoso Decreto de Graciano, também intitulado, em alguns manuscritos antigos, Concordia discordantium canonum e que data de cerca de 1140. Como se sabe, é a Graciano - monge camaldulense do século XII - que se atribui a paternidade do Direito Canônico, vigente até 1917. Neste Decreto, convergiam documentos de várias espécies e de diferentes proveniências, tais como textos bíblicos e patrísticos, escritos de autores eclesiásticos, cânones, decretais, livros penitenciais e obras da literatura jurídica profana, sobretudo aquelas oriundas do direito romano. Como se pode constatar, tratava-se mais de uma compilação, uma sistematização

${ }^{5}$ Cf. CHENU, M.-D. La théologie comme science au XIIIe siècle, 1969, p. 20. 
e um ordenamento de leis a serviço do magistério e da direção da Igreja do que propriamente de uma obra de reflexão e indagação.

Todavia, Pedro Abelardo designará pelo nome de theologia a disciplina que se apresentava sob os nomes de sacra doctrina, lectio divina, sacra scriptura, sacra pagina, etc. Note-se, contudo, que estas denominações persistirão sob a pena de vários autores medievais, inclusive sob aquela de Tomás de Aquino, que se servirá de algumas destas expressões na própria Summa Theologiae. Ajunte-se, porém, que não foi por acaso que Abelardo colocou o termo "theologia" como componente principal dos títulos das três obras que formam, por assim dizer, a sua síntese doutrinal: Theologia Summi Boni, Theologia Christiana e Theologia Scholarium. Certo, o foco de seu interesse e de suas reflexões nestas obras é a doutrina trinitária. Todavia, ele procede a uma evolução ou, mais exatamente, a uma reinterpretação e revaloração destes escritos na medida em que, na Theologia Christiana e na Theologia Scholarium, o acento se desloca para temas que incluem, por exemplo, a questão das relações entre Deus e o mundo, o problema do mal, e outros. Já na primeira obra, Theologia Summi Boni, o que ainda predominava era a polêmica com o seu antigo mestre, Roscelino, em torno dos universais. Em Sic et Non, emergirá um novo fator. Trata-se - como o seu próprio nome já o indica - do binômio ou, mais exatamente, da tensão entre a ratio e a auctoritas, que consistia em dirimir as questões e os pontos de divergência, de atrito e até mesmo de contradição que acarretavam a leitura das Escrituras e a formulação das diferentes doutrinas. Este novo método irá transformar, a partir das tensões que ele próprio suscita, o tradicional procedimento de compilar e comentar os Padres da Igreja e passagens das Escrituras, que era prioritariamente baseado na voz da auctoritas. Pelo termo "auctoritas", os escolásticos queriam significar a tradição e, mais exatamente, tudo aquilo que se achava expresso nos ditos das Escrituras, dos Padres da Igreja, nos símbolos e nas decisões conciliares. No entanto, com o novo método do Sic et Non, e com as leituras e os comentários que se faziam através de obras habitualmente intituladas "Sentenças", passava-se agora a colecionar, ordenar e, principalmente, a comentar as sentenças dos Padres da Igreja e as Escrituras. Dentre as obras mais conhecidas deste período se destacavam os Libri quarttuor sententiarum de Pedro Lombardo, morto em 1160, e não por acaso cognominado o "Mestre das sentenças". Há também as Questões ou Sentenças de Anselmo de Laon (c. 1050-1117), as Sentenças de Guilherme de Champeaux (c. 1070-1122), as Sentenças de Roberto Pullus (morto em 1150), as Sentenças de Roberto de Melun (c. 1100-1167) e as Sentenças de Simão de Tournai (1130-1201).

No entanto, será com Pedro Abelardo - repita-se - que se assistirá a um deslocamento fundamental do método e da maneira de organizar o acervo cultural da tradição cristã, porquanto o lógico francês não mais irá servir-se do termo "sentença", mas da palavra "summa" para desenvolver verdadeiros tratados que não mais se limitarão a compilar, organizar e comentar 
passagens das Escrituras e dos Padres da Igreja. Com e a partir do autor do Sic et Non, nota-se também um verdadeiro empenho em sintetizar e, melhor ainda, em aplicar uma análise lógica às chamadas verdades reveladas ou transmitidas pela auctoritas. É, portanto, nesta nova acepção que Abelardo se servirá do termo "summa" que, de resto, se encontra também em Hugo de São Vítor (c. 1096-1141) e, mais precisamente, no prólogo do Livro I do De sacramentis christianae fidei. Convém, todavia, salientar que é principalmente a partir de 1200 que este termo passará a substituir mais frequentemente aquele de Sentença para justamente significar o estudo da teologia que, a partir de Abelardo, adquirira o status de ciência, vale dizer, uma exposição racional e sistemática do conjunto das doutrinas da fé cristã. Mas com esta nova produção filosófico-teológica, com a fundação das universidades e, notadamente, com a entrada de Aristóteles no proscênio do mundo latino, começa uma nova era, que é aquela do apogeu da Escolástica.

\section{O século XIII: Aristóteles, as Universidades e a fragmentação do saber}

Urge, no entanto, lembrar que a entrada de Aristóteles no cenário do pensamento cristão não se deu de maneira brusca e repentina, mas gradual e sinuosamente. De resto, foi também paulatinamente que ocorreu a fundação das universidades. A primeira a ser fundada foi a Universidade de Paris, em 1200, seguidas das Universidades de Oxford, Cambridge, Montpellier, Toulouse, Salamanca, Valladolid, Nápoles e outras. Na verdade, a Universidade de Bolonha remonta ao final do século XI e, mais exatamente, ao ano de 1088. Todavia, durante um longo período, ela funcionou mais como um centro de estudos jurídicos do que propriamente como uma universidade típica dos séculos XIII e XIV. De sorte que foi somente em 1352 que o papa Inocêncio IV a dotou de uma faculdade de teologia regular. Estas universidades vieram, de fato, eclipsar a antiga dinâmica do ensino que era ministrado nas escolas claustrais e naquelas outras construídas à sombra das catedrais que, por isso mesmo, eram chamadas de "escolas episcopais". Deve-se, porém, evitar confundir ou identificar a universidade medieval com a universidade dos tempos modernos, porquanto a configuração, a distribuição espacial e o funcionamento da Universitas medieval diferem totalmente do que hoje se entende pelo termo "universidade". A Universitas medieval não era organizada e centrada num determinado lugar, nem tampouco formava ela um conjunto de edifícios estabelecidos em diferentes pontos de uma cidade. Ela se apresentava antes de tudo como uma realidade intelectual, na qual professores e alunos, perseguindo objetivos comuns, participavam do ensino ministrado e distribuído numa mesma cidade. A sua constituição física e curricular se apresentava da 
seguinte maneira: havia o studium generale, ou universale, ou commune, que não era o espaço onde se exploravam conhecimentos gerais, mas o centro de estudos em que alunos de diversas proveniências podiam ser acolhidos; havia também o studium particulare da província, para onde a ordem enviava os alunos pertencentes àquela província; havia finalmente o studium solemne que, não sendo necessariamente um studium generale, destacava-se, porém, como um centro de estudos particularmente célebre e altamente frequentado. ${ }^{6}$ Mas a própria figura do universitário medieval diferia também daquela do intelectual moderno. Segundo Alain de Libera, numa interpretação, de resto, contestável, a universidade medieval foi o ponto de partida durável de uma divisão do trabalho, cuja realidade se deixa hoje formular da seguinte maneira: a função do intelectual moderno, à diferença do universitário medieval, se manifesta antes de tudo como uma função "crítica". Assim: "O intelectual é um ator da mudança social, enquanto que o universitário (medieval) é um espectador indiferente". ${ }^{7}$ Esta é, de fato, uma ilação gratuita, genérica e sem fundamento na realidade do universo cultural da Idade Média. Pois as universidades e, antes delas, as escolas claustrais e episcopais eram centros de uma ebulição intelectual que repercutia, direta ou indiretamente, na visão de mundo do homem comum, sobretudo a partir do século XIII, quando propriamente começa a expansão urbana e, pouco a pouco, começa também a delinear-se a figura do Estado.

Antes, porém, da fundação das universidades, o ensino superior se fazia, conforme mais acima avançamos, nas escolas claustrais e nas escolas catedrais. Em Paris especificamente, havia, em meados do século XII, três centros principais de ensino superior: as escolas da catedral de Notre-Dame, dirigidas por um chanceler que, por sua vez, estava sob a autoridade do bispo da cidade; as escolas dos cônegos regulares de São Victor, cuja ênfase era dada sobre a mística; e as escolas situadas sobre a colina de Santa Genoveva, na abadia do mesmo nome. Note-se, contudo, que as escolas de Notre-Dame se sobrelevavam às demais quanto à qualidade do ensino e do corpo docente, de sorte que foi a partir desses centros de estudo que se originou a Universidade de Paris. Esta se compunha essencialmente de quatro faculdades: a Faculdade de Filosofia, ou de Artes, em recordação do ensino das artes liberais; a Faculdade de Teologia e, finalmente, as Faculdades de Direito e de Medicina. A partir de meados do século XIII, a filosofia que predominou na Faculdade de Artes foi aquela de Aristóteles, enquanto que na Faculdade de Teologia as lições se faziam sobretudo a partir das Escrituras e do Livro das Sentenças de Pedro Lombardo, referência principal nas escolas. Sublinhe-se, porém, que essa preferência com relação a Pedro Lombardo era devida não somente à sua autoridade intelectual,

${ }^{6}$ Cf. GILSON, É. La philosophie au Moyen Âge, 1999, p. 391.

${ }^{7}$ LIBERA, A. de. Penser au Moyen Âge, 1991, p. 143. 
mas também, e principalmente, ao fato de a teologia de Abelardo ser mantida à distância do magistério e do ensino oficial da Igreja em virtude das suspeitas e da condenação que sofreram suas teses.

Não menos digno de nota é o fato de que dificilmente se poderia encontrar no século XIII - como, de resto, nos séculos anteriores - um pensador que fosse totalmente aristotélico ou totalmente neoplatônico. Considere-se, por exemplo, a obra de Tomás de Aquino que, graças às influências de Agostinho, de Dionísio Areopagita e, indiretamente, das filosofias arábica e judaica, é permeada de elementos neoplatônicos. Quanto a Boaventura, que retoma os temas filosóficos e teológicos típicos de Agostinho e de Anselmo de Aosta, ele não hesita, às vezes, em utilizar-se de uma linguagem aristotélica para melhor expressar seu raciocínio e, assim, sustentar as suas teses principais. Já um pensador como Siger de Brabante, é mais pertinente considerá-lo um averroísta do que propriamente um aristotélico. Mas se é difícil, ou impossível, encontrar um puro aristotélico ou um puro platônico no universo da Escolástica, ou das Escolásticas, não menos difícil será deparar um pensador cristão que se mova exclusivamente no âmbito das Escrituras e um pensador muçulmano ou judeu cujas únicas referências sejam, respectivamente, o Alcorão e as Escrituras.

O entrelaçamento de platonismo, aristotelismo e Sagradas Escrituras torna-se ainda mais visível se levarmos em conta a grade curricular e o método fundamental do ensino ministrado nas universidades a partir de 1200 . Certo, por um lado, no que tange às duas maiores faculdades da Universidade de Paris, os estudos se desenrolavam através de duas correntes principais: o aristotelismo da Faculdade de Filosofia e o neo-agostinismo da Faculdade de Teologia. Inegável também é o fato de que os dominicanos representavam, de um modo geral, a tendência aristotélica, enquanto que a grande maioria dos franciscanos conservava a tradição neoplatônica, ou neo-agostiniana. Por outro lado, porém, a maioria desses pensadores era composta de teólogos, e não de filósofos no sentido estrito do termo. Dentre esses teólogos, se destacavam os dominicanos Alberto Magno e Tomás de Aquino, enquanto que na ala franciscana sobressaíam os nomes de Boaventura e João Peckham e, entre os agostinianos, o de Egídio Romano. Ademais, havia os mestres "seculares", assim chamados por não pertencerem a nenhuma ordem religiosa e cujos principais representantes eram: Boécio de Dácia, Siger de Brabante, Godofredo de Fontaines e Henrique de Gand, paladino inflexível da liça conservadora do agostinismo. Eles não eram teólogos, mas artistae, ou magistri artium, justamente por lecionarem na Faculdade de Artes.

No que concerne à Escolástica de tipo árabe e judaica, a diversidade e imbricação entre os diferentes saberes se torna ainda mais complexa e, portanto, mais difícil de se precisar, na medida em que os neoplatonismos que a caracterizam são mais sutis, embora mais visivelmente presentes na 
sua concepção da criação e da revelação. Na verdade, as próprias filosofias arábica e judaica, tais como foram influenciadas pelos escritos do Estagirita a partir da tradução siríaca e, depois, da versão arábica, já se apresentam como tentativas de síntese do aristotelismo e do platonismo, tendo como pano de fundo o Alcorão e as Escrituras. Assim, enquanto o filósofo judeu Moisés Maimônides (1138-1204) buscava estabelecer uma conciliação entre Aristóteles e as Escrituras, os muçulmanos, por sua vez, procuravam conciliá-lo com a revelação contida no Alcorão. É o que se verifica, por exemplo, em Alfarabi, em quem o peripatetismo arábico tentara lançar uma ponte entre a teoria do céu, a doutrina das inteligências motoras e aquela do profetismo. De resto, uma de suas obras mais significativas se intitula, precisamente: Concordância de Platão e de Aristóteles. Quanto ao primeiro grande nome da chamada filosofia "muçulmana", Alkindi (c.796-c.873), ele sobressai notadamente como um grande enciclopedista, cujos escritos compreendem quase todos os domínios do conhecimento grego: a aritmética, a geometria, a astronomia, a música, a óptica, a medicina, a lógica, a psicologia, a meteorologia e a política. No seu tratado, Liber de intellectu, onde ele pretende discorrer "segundo a sentença de Platão e de Aristóteles", Alkindi tenta esclarecer a origem dos universais a partir de uma explicação da natureza e da capacidade de abstração que possui o intelecto humano. ${ }^{8}$

Certo, o médico e filósofo persa Avicena que, juntamente com o cordovês Averróis, iluminou com um esplendor inigualável o céu da filosofia árabe, introduziu no aristotelismo o conceito de criação. Aqui, porém, não se trata de uma criação propriamente dita, pelo menos daquela criação concebida nos moldes do Alcorão e das Escrituras. Trata-se, antes, de uma criação pensada e construída a partir do modelo neoplatônico de uma emanação ou, mais exatamente, de uma processão, pois ela consiste numa saída das coisas do seio de Deus segundo uma escala de maior ou menor perfeição. Assim, quanto mais próximas se encontrarem do Criador, tanto mais perfeição ou, poderíamos ajuntar, consistência ontológica, terão elas. Consequentemente, o mundo é eterno, porque igualmente eterna é a sua primeira causa enquanto una e simples. De modo semelhante, a prova de que os céus não foram criados se encontra na sua própria incorruptibilidade. Mas como conciliar esta ilação com a doutrina da criação, tal como a concebe o Alcorão? É que, segundo Avicena, os próprios céus não são causa da sua existência, porquanto a causa ou as causas de sua existência os precederam enquanto Inteligências imateriais. ${ }^{9}$ Mas, se é assim que se apresenta a criação para Avicena, como então ela é concebida pelo outro exponente da filosofia arábica, Averróis?

${ }^{8}$ Cf. GILSON, 1999, p. 346.

${ }^{9}$ Cf. BRÉHIER, É. La philosophie du Moyen Âge, 1971, p. 189. 
Para Averróis igualmente - em quem é patente a influência do islamismo, de Aristóteles e de Plotino - a existência inteira se afigura como uma ordem rigorosamente hierarquizada, porquanto todo ser ocupa um lugar e uma função que lhe são especificamente assinalados. Certo, no vértice da cadeia ontológica se encontra Deus, mas um Deus que não se manifesta propriamente como o Criador do universo, porquanto o movimento, e mesmo a matéria do mundo, são eternos. Esta é a razão pela qual em Averróis, assim como em Avicena, não existe propriamente uma criação do mundo, pois, atendo-se à perspectiva plotiniana, Deus produz eterna e imediatamente a primeira Inteligência, da qual derivam, ou procedem, as demais Inteligências das esferas celestes. Mas o mundo, na concepção de Averróis, é não somente eterno; ele é também necessário e único. E ele é único porque o Uno não pode senão produzir um efeito único. Consequentemente, uma pretensa composição ou multiplicidade do mundo é contrária ao princípio segundo o qual, no conhecimento intelectual, inteligência e inteligível são idênticos. Ademais, o filósofo ajunta que todas estas dificuldades não procedem diretamente de Aristóteles, mas de pensadores e comentadores que não aceitam que o bem e o mal e, em geral, os opostos, derivam de uma causa única. ${ }^{10} \mathrm{~A}$ partir destas concepções, podemos melhor entender os ataques - diretos com relação a Aristóteles, indiretos vis-à-vis de Avicena e Averróis - que Maimônides desenvolve no Guia dos perplexos ao falar da criação do mundo e dos seres em geral. Para o filósofo judeu, é evidente que as coisas criadas, ou causadas, são o produto de uma intenção daquele que as criou, e não de uma consequência necessária. ${ }^{11}$

Considerando-se, pois, a diversidade, a pluralidade e, consequentemente, a fragmentação dos saberes que se vinha intensificando nos séculos anteriores e que culminaram na Alta Escolástica, não é de admirar a quantidade ingente de "Sumas" que, ao se multiplicarem ao longo do século XIII, exprimem justamente a necessidade de sintetizar ou epitomar um saber que se diversificara em demasia. Pense-se, por exemplo: na Summa quaestionum theologicarum, ou Summa de bono, de Filipe o Chanceler, a Summa Fratris Alexandri, atribuída a Alexandre de Hales, a Summa de creaturis e a Summa theologica de Alberto Magno, a Summa philosophiae da escola de Roberto Grosseteste, as Summae quaestionum ordinariarum de Henrique de Gand, a Summa theologiae e a Summa contra Gentiles de Tomás de Aquino, as Summulae logicales de Pedro Hispano, a Summa de Ulrico de Estrasburgo, intitulada, De summo bono, e mais tarde, no século XIV, a Summa totius logicae, a Brevis summa libri physicorum e a Summula philosophiae naturalis de Guilherme de Ockham. O século XV viria surgirem as Summulae logicae e a Summa naturalium de Paulo Vêneto. Estes títulos de "sumas" que citamos, somados a outros que aqui deixamos de aduzir, só fazem

${ }^{10}$ Cf. BRÉHIER, 1971, p. 200.

${ }^{11}$ MAIMÔNIDES, M. La guida dei perplex, 2005, p. 381. 
reforçar a ideia de que eles apontam não somente para o status de cientificidade que alcançara o saber teológico no apogeu da Escolástica, mas também - repita-se - para a sua extrema fragmentação e diversificação que se vinham avultando desde a Primeira Escolástica e, principalmente, desde o século XII. ${ }^{12}$ Tudo isto veio deslocar a perspectiva da relação fé e razão, colocando-a sobre uma nova ordem e um novo patamar epistêmico, porquanto não mais se tratava, como nos primeiros séculos da era cristã ou, mais precisamente, no período apologético (séculos II-III), da relação "sabedoria cristã" e "sabedoria pagã". Não se tratava tampouco, como nos séculos subsequentes, da relação "filosofia" e "doutrina cristã". O que agora estava em jogo era a tentativa de justificar e demonstrar - de maneira racional e argumentativa - a "cientificidade" no interior mesmo da teologia. Mas como isso seria possível? Pode-se a rigor submeter os dados da fé a uma verificação e demonstração científicas? Em outros termos, é possível falar da teologia - do discurso sobre Deus - como se procede com relação a uma ciência?

\section{A relação fé e ciência: pode a teologia ser uma ciência?}

Com efeito, ao ser elevada à ordem de um saber sistemático e racionalmente demonstrável, a doctrina christiana - designada doravante pelo nome de "teologia" - passou a ser submetida a métodos externos à sua própria constituição. Com isto, ela extrapolava o âmbito exclusivo, ou quase exclusivo, do comentário de passagens das Escrituras e das sentenças dos Padres da Igreja, com o auxílio das artes liberais. Consequentemente, a razão interferia diretamente na fonte principal de onde hauria a tradição cristã para conhecer a Deus: as Escrituras e a literatura patrística. É neste ponto, porém, que retorna a questão: até que ponto é possível falar racionalmente, cientificamente, metodicamente, de Deus? Certo, Abelardo, ao mesmo tempo em que assinala à teologia um estatuto de cientificidade, insiste também sobre o caráter inefável da majestade divina e, consequentemente, sobre a impossibilidade de a linguagem encontrar um único conceito capaz de atingir e, muito menos, de determinar a sua essência. Donde a necessidade, segundo o lógico francês, de se falar sobre Deus através de similitudes, translações e enigmas figurados (translationibus et parabolicis enigmatibus). ${ }^{13}$ Quanto a Tomás de Aquino, ele é categórico ao afirmar, já no início da Suma Teológica, que a "sacra doctrina" é uma ciência. Mas em que sentido?

${ }_{12}$ Para a questão da diversidade e heterogeneidade do saber, ou dos saberes, na Idade Média, veja: ALMEIDA, Rogério Miranda de. A fragmentação da cultura e o fim do sujeito, 2012, Capítulo II.

${ }^{13}$ Cf. ABELARDO, Pedro. Teologia del sommo bene, 1996, Libro II, Cap. III, 78. 
Para o Aquinate, há várias ciências que, tomadas individualmente, reenviam a duas principais espécies de ciência. Algumas ciências procedem de um princípio conhecido pela luz natural da inteligência, tais como a aritmética, a geometria e quejandas. Outras, porém, derivam de princípios conhecidos pela luz de uma ciência mais elevada; é o caso, por exemplo, da ciência óptica, que se orienta a partir de princípios estabelecidos pela geometria, e da música, que tem como princípios a aritmética e as leis da harmonia musical. Ora, a "sacra doctrina" procede de princípios estabelecidos pela luz de uma ciência mais elevada, a saber, a ciência de Deus e dos bem-aventurados. Consequentemente, assim como o músico aceita, como autoridade, os princípios que comandam a matemática, assim também a "sacra ciência" se baseia nos princípios que lhe são revelados por Deus. ${ }^{14}$

Desta definição, ou destas definições, da ciência pode-se tirar uma ilação que, na verdade, se transforma numa interrogação que irá acirrar ainda mais a já problemática questão da relação fé e ciência. Com efeito, ao invés de considerarem a fé e a ciência como dois domínios que se incluiriam, se complementariam ou se suporiam mutuamente, não teriam estas definições acentuado ainda mais o fosso que as separa irremediavelmente? Em outros termos, onde termina a intelecção da fé pela razão e onde começa a aceitação, por esta mesma fé, de um conhecimento que resiste e escapa a toda tentativa de dominação do discurso racional? Para dizê-lo sob a forma de tese: fé e razão, fé e ciência, se completam, se supõem ou se excluem pura e simplesmente?

Ora, a tentativa de apreensão ou de investigação racional dos dados da fé já se encontrava no Primeiro Livro da Suma contra os Gentios, onde o Aquinate tratava justamente de Deus e das implicações que decorrem do esforço para conhecê-lo. Aqui, Tomás de Aquino se servia do método da analogia e, mais precisamente, da noção de participação como um dos meios aptos a nos aproximar do conhecimento de Deus. Mas de que modo ele procede? Há, segundo o Doutor Angélico, uma dupla maneira pela qual se pode professar ou procurar a verdade acerca de Deus. Algumas verdades excedem totalmente a capacidade da razão humana, tais como a afirmação de que Deus é Trino e, ao mesmo tempo, Uno. Há, porém, outras verdades acerca de Deus que, segundo o Aquinate, a razão natural é capaz de alcançar por ela mesma, por exemplo, que Deus existe, que ele é Uno, e outras verdades que foram demonstradas por todo filósofo que se deixou guiar pela luz da razão natural. Todavia, introduz-se aqui uma ressalva: o intelecto humano não é capaz de atingir uma compreensão da substância divina no sentido que este termo, substância, tinha para o Estagirita. Para Aristóteles, de fato, uma substância é aquilo "que uma coisa é" enquanto princípio de sua própria demonstração. Ora, no universo empírico em

${ }^{14}$ Cf. TOMÁS DE AQUINO, Summa Theologica, 1947, I, q. 1, a. 2. 
que se movia o pensamento aristotélico-tomasiano, o intelecto depende da sensibilidade enquanto fonte, origem e meio para se conhecerem as realidades. Destarte, nada que não provenha dos ou através dos órgãos do sentido jamais poderá ser apreendido pelo intelecto humano. Mas se as coisas se apresentam assim, o intelecto está fadado a jamais poder captar a essência divina a partir das realidades sensíveis, porquanto, na condição de efeitos e de coisas efêmeras e instáveis, elas nunca serão suficientes para nos fazer plenamente alcançar a potência última de sua causa. No entanto, o Aquinate vê-se obrigado a admitir que, pela ascensão através das coisas sensíveis, isto é, dos efeitos às suas causas, o intelecto poderá - de certo modo - chegar ao conhecimento da existência de Deus. E não somente ao conhecimento da existência de Deus, mas também daquelas outras características que se atribuem à primeira causa, ou ao Princípio, ou, em última análise, a Deus. Donde a conclusão do teólogo: “Há, por conseguinte, algumas verdades inteligíveis acerca de Deus que são acessíveis à razão humana; há outras, porém, que ultrapassam totalmente a sua capacidade". ${ }^{15}$

A conclusão a que chegara Tomás de Aquino na Suma contra os Gentios - se é que realmente ele chegara a uma conclusão - será ampliada, aprofundada e, melhor ainda, problematizada no comentário sobre a Trindade, de Boécio (Super Boetium de Trinitate). ${ }^{16}$ Na questão II, artigo, 2, deste tratado, o Aquinate inicia seu raciocínio, como é próprio do seu método fundamental, pelas objeções levantadas contra uma determinada tese. Neste caso particular, a tese se enuncia deste modo: "Se é possível uma ciência das coisas divinas". A objeção 5 diz, com efeito, que toda ciência se apresenta como um saber que procede de princípios evidentes ou conhecidos por eles mesmos: "Omnis scientia procedit ex principiis per se notis" ${ }^{17}$ Todavia, mais uma vez retorna a mesma interrogação: como então falar de uma ciência acerca de Deus, se os artigos de fé - que se reportam aos primeiros princípios tão somente a partir da própria fé - não são conhecidos de maneira evidente nem podem, a fortiori, ser reconduzidos pela via da demonstração aos princípios conhecidos por eles mesmos? Para responder a esta objeção, o teólogo se serve daquela mesma definição de ciência que encontramos na Suma contra os Gentios, a saber, existe uma dupla ciência (duplex scientia) das coisas divinas. Uma destas ciências diz respeito ao nosso próprio modo de conhecer que, partindo das coisas sensíveis, delas

\footnotetext{
15 TOMÁS DE AQUINO, Summa Contra Gentiles, 1975, I, 3.

${ }^{16}$ Os estudiosos costumam colocar a data da redação do Super Boetium de Trinitate entre os anos 1255 e 1259, isto é, durante a segunda metade do período do magistério do Aquinate em Paris. Quanto à Suma contra os Gentios, concorda-se em afirmar que a sua composição teve início em 1259 e que a obra deve ter passado por diferentes remanejamentos até 1264, e mesmo depois.

${ }^{17}$ TOMÁS DE AQUINO, Super Boetium de Trinitate, 1997, q. II, a. 2, ob. 5.
} 
retira seus princípios para chegar - através da analogia - às realidades divinas. Foi assim - diz o Aquinate aludindo a Aristóteles e à tradição aristotélica - que procederam os filósofos ao tentarem construir uma ciência divina, que eles designavam pela expressão: "filosofia primeira". A segunda via, completa o teólogo, concerne ao modo como são conhecidas as próprias coisas divinas, ou seja, a partir delas mesmas e por elas mesmas. Mas, considerando-se o nosso estado de criaturas, um conhecimento desta espécie estaria, desde o início, fadado ao mais completo fracasso. Só resta então ao teólogo uma saída: apelar para a fé. E ele o faz recorrendo à doutrina da participação, na medida em que, conforme determina esta doutrina, é possível que os seres humanos participem de alguma maneira, e até uma certa medida, do conhecimento das coisas divinas. Todavia, ele ajunta logo em seguida que isto só será possível se os homens forem agraciados pela fé infusa; só assim poderão eles avizinhar-se da primeira verdade, que é o próprio Deus. ${ }^{18}$

Permanece, pois, a questão de saber se, a rigor, o conhecimento pela fé, que supõe a graça infusa, pode ser considerado uma ciência no sentido aristotélico do termo. Certo, para que a acepção aristotélica de ciência se torne compatível com a intelecção dos dados da fé tal como o Doutor Angélico a compreende, ela deverá ser transformada, reelaborada e, portanto, adaptada à sua própria perspectiva básica, que é a perspectiva cristã. A este respeito, porém, M.-D. Chenu chama a atenção para uma incompatibilidade fundamental, radical, que reina entre a ciência e a fé. A primeira, diz ele, "procede a partir de uma evidência", enquanto que a fé caminha pari passu com a revelação. Ademais, a ciência é adquirida, enquanto que a fé é infusa. Ajunte-se a isto que a ciência tem por objeto o universal, enquanto que as Escrituras tratam, do começo até o fim, de fatos singulares, concretos, tangíveis. ${ }^{19}$ Não se pode, pois, evitar esta interrogação fundamental: em que nível epistêmico se coloca finalmente Tomás de Aquino? Mais precisamente: fé e ciência se completam? Fé e ciência se mediam ou, antes, apontam elas para uma problemática mais profunda e mais primordial ainda?

\section{Conclusão}

Este parece, com efeito, ser o legado que deixaram os séculos XII e XIII: a intensificação e explicitação da tensão que sempre marcou as relações entre as teorias provindas da filosofia de Aristóteles e aquelas advindas da tradição agostiniana. Paul Tillich, no seu estudo intitulado: Uma história do

\footnotetext{
${ }^{18}$ Cf. Tomás de Aquino, 1997, ibid., q. II, a. 2, Responsio.

${ }^{19}$ Cf. CHENU, M.-D., 1969, p. 68.
} 
pensamento cristão, aponta para este abismo que se escavou e se aprofundou entre as duas principais tradições do pensamento filosófico-teológico que culminou, no século XIII, com Tomás de Aquino e, mais tarde, com Duns Escoto (1266-1308) e Guilherme de Ockham (c. 1285-c. 1349). Segundo Tillich, o método aristotélico da teoria do conhecimento - que começa com as realidades do mundo exterior - foi aquele que realmente terminou prevalecendo sobre a sua contrapartida: a doutrina da "iluminação interior". Todavia, argumenta o teólogo, Tomás de Aquino sabia que as conclusões alcançadas pelo método empírico do conhecimento, embora logicamente corretas, não seriam suficientes para produzirem uma real conviç̧ão sobre Deus. Consequentemente, elas deviam ser completadas pela autoridade, ou a auctoritas, no sentido escolástico do termo. Já para o franciscano Boaventura, o conhecimento se dava de maneira teonômica em todos os domínios da vida, ou seja, não existe outra maneira de se conhecer senão aquela que começa com Deus, ou a partir de Deus. Assim, Tomás de Aquino, que privilegiava o método autônomo do conhecimento, método este que podia desenvolver-se até um certo limite, teria sido o responsável por este fosso que se vinha aprofundando, cujas consequências, porém, não se podiam ainda prever. Todavia, completa Tillich, seria com Duns Escoto que este abismo iria finalmente, e inevitavelmente, abrir-se de par em par. $^{20}$

Efetivamente, dado que Duns Escoto era um pensador "radical", e não um pensador da mediação, ele rompeu aquilo que, até então, parecia formar uma unidade. Sem embargo, ele não seguiu seus predecessores franciscanos. Certo, ele propendia para Tomás de Aquino ao aceitar o método fundamental de Aristóteles, mas logo compreendeu as consequências que o Aquinate, de certo modo, fora apto a refrear, ou a encobrir. É que, para Duns Escoto, existe um intransponível abismo entre o finito e o infinito, de sorte que o finito jamais poderá atingir a Deus pelo conhecimento. Isto se revela impossível tanto em termos de uma imediatidade - como queriam os antigos franciscanos - quanto através de demonstrações racionais, mediatas. Consequentemente, assim como Tomás de Aquino já pressupusera antes, também para Duns Escoto só existe uma via capaz de aceder a Deus: é a via da auctoritas ou, mais exatamente, da revelação recebida pela autoridade da Igreja. ${ }^{21}$

O fosso que se achava velado sob a pena, o raciocínio e as demonstrações de Tomás de Aquino se mostra agora, e doravante, escancarado, desvelado e, literalmente, incontornável. E ele se aprofundará e se ampliará ainda mais com Guilherme de Ockham, na medida em que Deus só poderá ser alcançado se nos submetermos às autoridades escriturística e eclesiástica.

${ }^{20}$ Cf. TILLICH, Paul. A History of Christian Thought. From its Judaic and Hellenistic Origins to Existentialism, 1968, pp. 186-187.

${ }^{21}$ Cf. TILLICH, 1968, p. 187. 
Mas, para isto, temos de ter o habitus, isto é, a graça habitual. Assim, torna-se também patente que o conhecimento filosófico, científico e cultural é livre e autônomo, enquanto que o conhecimento obtido pela fé, ou pela revelação, é completamente heterônomo. A consequência de tudo isso não poderia ser outra: aquela teonomia original que havia caracterizado a tradição agostiniano-franciscana foi rompida; de igual modo, evidenciou-se em plena luz o abismo que Tomás de Aquino tentara encobrir através das mediações: fé e razão, fé e ciência, graça e natureza. De sorte que o que agora temos é, de um lado, a autonomia científica e, de outro, a heteronomia eclesiástica. Donde a ilação que, sob a forma de resumo, Tillich é obrigado a tirar: "Em Tomás de Aquino, a razão é apta a exprimir a revelação. Em Duns Escoto, a razão é inapta a exprimir a revelação. Em Ockham, a revelação caminha ao lado da razão, e mesmo em oposição a ela". ${ }^{22}$

Ora, esta dicotomia que se achava ainda velada em Tomás de Aquino, que Duns Escoto aprofundou e Guilherme de Ockham levou à sua radicalização máxima se acha na origem de muitos dos traços que caracterizam o saber e a ciência dos tempos modernos, um saber e uma ciência que reivindicam, sobretudo a partir de Kant, a sua autonomia, a sua emancipação, a sua liberdade ou, para dizê-lo kantianamente, a sua maioridade. Se voltarmos mais uma vez aos séculos XII e XIII - quando, com este último, a Escolástica atingiu o seu ápice -, se considerarmos enfim o século XIV, quando, com Duns Escoto e Guilherme de Ockham, a Escolástica marcha para a sua desintegração cedendo o espaço para uma nova dinâmica de forças e de revalorações, não poderemos evitar a pergunta: a quem, afinal de contas, cabe a primazia, a Platão ou a Aristóteles? Ou aos dois ao mesmo tempo?...

\section{Referências:}

ABELARDO, Pedro. Teologia del sommo bene. Milano: Rusconi, 1996.

ALMEIDA, Rogério Miranda de. A fragmentação da cultura e o fim do sujeito. São Paulo: Loyola, 2012.

ARISTÓTELES. Metafisica. Milano: Bompiani, 2000.

BRÉHIER, Émile. La philosophie du Moyen Âge. Paris: Albin Michel, 1971.

CHENU, Marie.-Dominique. La théologie comme science au XIIIe siècle. Paris: Vrin, 1969.

DILTHEY. Wilhelm. Einleitung in die Geisteswissenschaften. Versuch einer Grundlegung für das Studium der Gesellschaft und der Geschichte. In Gesammelte Schriften, I. Band. Stuttgart: B. G. Teubner, 1990.

${ }^{22}$ TILLICH, 1968, p. 188. 
GILSON, Étienne. La philosophie au Moyen Âge. Paris: Payot, 1999.

KANT, Immanuel. Schriften zur Naturphilosophie. In Werkausgabe in 12 Bänden, IX. Frankfurt am Main: Suhrkamp, 2003.

LIBERA, Alain de. Penser au Moyen Âge. Paris: Seuil, 1991.

MAIMÔNIDES, Moisés. La guida dei perplexi. Torino: UTET, 2005.

PLATÃO. La République. Paris: GF Flammarion, 2004.

TILLICH, Paul. A History of Christian Thought. From its Judaic and Hellenistic Origins to Existentialism. New York: Simon and Schuster, 1968.

TOMÁS DE AQUINO. Commenti a Boezio. Milano: Rusconi, 1997. Summa Theologica. New York, Benziger Brothers, 1947, vol. I. Summa Contra Gentiles. Book One: God. Notre Dame: University of Notre Dame Press, 1975.

Endereço do Autor:

R. Carmelo Rangel, 1.200

Batel

80440-050 Curitiba - PR

r.mirandaalmeida@gmail.com 